\title{
Impact of Spiritual intelligence in Leadership: Some Biblical Cases
}

\author{
Pitshou Moleka
}

Affiliation: mRAN (managing research African network), Kinshasa/DR Congo.

Email: sodecordc1@gmail.com

\section{Abstract}

Spiritual intelligence had an impact on different biblical leaders, and in this text, we see some cases to serve as a sample (Joseph, Bezalel, and Daniel). In the Bible, this impact is demonstrated in innovations introduced by Joseph in Egypt, Bezalel the manager of the macro project of building in crisis time, Daniel the politician. It is the supreme intelligence and leaders are invited to make a shift from rationality to spirituality. The more leaders of organizations will use spiritual intelligence, the more leaders and followers will experience satisfaction, joy, accomplishment.

Keywords: spiritual intelligence, leadership, Bible, project management, supply chain , workplace spirituality, theology of work, construction, neuroscience, cognitive psychology, psychoanalysis, neurology.

Before showing this impact, let us begin by the definition of the spiritual intelligence, and its scientific basis.

\section{What is spiritual intelligence}

Spiritual intelligence or spiritual quotient (SQ) is a higher dimension, a dimension of intelligence activating the capacities in terms of new level of understanding, empathy, innovation, and emanating from an understanding deep of its goals and reasons of existence, causing an improvement of talents and work (Griffits, 2020).

Spiritual intelligence is seen as a transpersonal intelligence that transcends individual limits, a non-rational dimension unifying man with nature and with God.

In their works, Maslow, Jung, Fowler, noted the role of spirituality in the development of human personality traits and motives (Drigas and Mitsea, 2020).

For Zohar and Marshall (2000), this intelligence helps to answer the questions of the profound signification of things and their value, enabling to act in a broad perspective, it is the pinnacle of intelligence and allows us to make an adequate judgment on situations and to act accordingly. It allows the questioning of situations to see how to change them, and no longer be reactive but proactive, so no longer endure situations but become masters of them.

The scientific basis if spiritual intelligence is demonstrated by the work of Richard Griffits (2021).

\section{Scientific basis}

a. Psychology: Psychology Studies by cognitive psychologists show the benefits of mindfulness training (MBCT), especially in relation to anxiety and depression. 
b. Psychoanalysis: The works of Sigmund Freud and current psychoanalytic studies show how the ego grows by identifying with the states of the body and of the body.

c. Neurology: The researches in the field of neurology demonstrate that the spiritual dimension is in connection with the brain confirming that spiritual quotient is hardwired in the brain of human beings.

III. Biblical case one: Joseph in Egypt

\section{Context of Joseph narration}

Inspired by French philosopher Jacques Derrida, Yiu-Wing Fung (1999) shows a binary opposition in deconstructing the Joseph's story. In this epistemological perspective, there is a dualism in the concepts used such as presence vs absence, brother vs foreigner, life vs death...It constitutes a strategy of reading.

\section{Spiritual intelligence in the life of Joseph}

a. Visionary (by dream and purveyance), man of solution called in French "personneressource", an expert, a resource man that brings transformation in organizations. In his teenager, he received dreams for his bright future and it brings many struggles in his life but he overcame. In the book of Genesis 37, 19 his brothers qualified him as "master of dreams", an expert in dreams.

A dream in spiritual dimension is like a prophecy, a prediction of the future, and a medium to understand what is happening and will happen in your own life or in the world. Doctor Martin Luther King Jr pronounced in front of a crowd a sentence in a speech on August $28^{\text {th }} 1963$ : "I have a dream".

It was a prophecy for transformation of black condition and suppression of racial segregation.

A dream in management or leadership is like a vision of the desired future, it moves to action for its materialization.

For Burt Nanus (1995) best-seller author in leadership, a vision is an important component of a process that gives orientation continually to a structure or an organization. Without it, people are perishing because they lack direction as said in the Bible.

b. Dream interpreter (supreme wisdom from God): Egypt had reputation of a great country of science, knowledge and wisdom. Many work of scholars in Egyptology like Cheick Anta Diop : « Egypte ancienne et Afrique noire » (1989) and many others show the contribution of Egypt in many scientific fields, some sciences was invented by old Egyptians for example the geometry which was a sacred science of priests, and used for construction of pyramids.

Indeed, Winkler Andreas (2011) asserts that Egyptian priests and magicians was viewed as wises and specialist; the dreams was one of way they communicated with spirits and interpret their will. By divination and astrology, they predicted the future. They could interpret divine oracles, the movement of the celestial bodies like stars, moon. They were supposed possessing calendars of good and bad Day and the competency in chronomancy. But Joseph had another level of wisdom, the binah. He interpreted as prisoner two dreams and what he predicted to dreams interpretation arrived with precision (Genesis 40, 1-22). Two years after, Pharaoh had a dream but all council of wise men was not able to give him a true explanation because of their limitation in term of intelligence, wisdom and spirituality (Genesis 41, 1-8). 
Then Joseph was invented as a man of solution and gave him signification of his two dreams concerning economic life of this old superpower.

c. Ethical values:

- humility ( nevertheless he owned a higher level in interpreting dream, he spoke of God as source of this not his ego. He was not a narcissistic leader according to Freud category who often exhibits arrogance, dominance, self sufficiently, overconfident in their own abilities (Winkler, 2011).

- Integrity and loyalty: even if the wife of his boss sexually harassed him, he refused to commit sin in having sexual relation with her because of his integrity and loyalty to his boss Potiphar. Only profound spirituality can help live in integrity and loyalty.

- Forgiveness: he was sold as slave and hate by his brothers; he exercised no vengeance against them but loved them. He took care of them without grudge as a shepherd in front of his flock. He understood that trials are a school for preparing heart to great responsibility (Genesis 50, 18-21).

\section{d. Spiritual interpretation of events}

All events were interpreted with a spiritual meaning.

In Genesis 50, 19-21, he asks his bothers " am I in the place of God"?. For him the circumstances are under God's control, and what happen in life is not casual, the invisible hand of the master of the history in present.

Men intentions are opposed to God's intention, the evil changed to good. Men are instruments of God to accomplish his design.

We can see in Joseph's story a foreshadowing of Jesus death and resurrection. His pit symbolizing the condemnation in death and the throne of Egypt is enthronization in the right hand of the Father.

Pulse Jeffrey (2017: 177-210) showed others images of death and resurrection such as the separation with family and their reunion, the liberty after slavery, the tearing of his clothes as Jesus with the Roman soldiers.. .for Christians, it symbolizes the new life and its confession by baptismal water.

3. His managerial and leadership impact

a. Joseph and Supply chain management and the Logistic:

Yossi Sheffi (2017) thinks that Joseph is the greatest logistician presented in the Bible. Joseph's leadership qualities were visible even in prison : "And the keeper of the prison committed to Joseph's hand all the prisoners" (Genesis 39, 22). There he interpreted prophetically what the servants of the Pharaoh have dreamed. When Pharaoh himself had a dream and nobody could interpret it, Joseph was invited to give him interpretation by spiritual intelligence. Joseph seized the kairos and put his theory of economical cycle of seven years to practice:

"Behold, there come seven years of great plenty throughout all the land of Egypt: And there shall arise after them seven years of famine; and all the plenty shall be forgotten in the land of Egypt; and the famine shall consume the land ". He gave to Pharaoh a plan to build a decentralized warehousing system.

Some principles learnt from Joseph's action: 
First, to avoid supply chain disruptions; second, to know how the supply chain can continue to deliver goods during crisis periods; all this was made possible by the spiritual gift, the binah.

b. A man with high business acumen: Like his father Jacob, Joseph was an operator, a business with a business acumen, knowing how to use his gifts and talents, to seize opportunities so that he rises from prison to a position of prominence as powerful man in a foreign country.

\section{Biblical case two: Bezalel}

Master Sergeant Russell E. Gehrlein (2018) quoting Gene Veith, in his book, "God at Work: Your Christian Vocation in All of Life", states that this text of building tabernacle is "the first explicit treatment of the doctrine of vocation in the Bible." Ex. 25, 8-31:11 lays out Yahweh's detailed instructions to Moses regarding the design and construction of the tabernacle, its components. There are several implications. It speaks about theology of work, the spiritual dimension in the work.

This text dealing with the men filled by the Sprit to build is an echo in the New Testament concerning spiritual gifts for the building up of the church or the body of Christ. Many parallels can be found between the construction of tabernacle, the re-creation accounts in Genesis and Exodus. Noah spends 40 days and nights awaiting re-creation (Genesis 7,12) and sets up an altar afterwards (Genesis 8,20), Moses spends 40 days and nights listening to God's instructions for the new life which awaits the newly liberated people of Israel (Exodus 24,18; 34,28 ), and then he descends to supervise the construction of the tabernacle (Exodus 25$31 ; 35-40)$. A connection can be established between the work of God and the work of his people. We can see Bezalel as a project manager filled with Spirit and hokhmah. He was able to bring innovation, creativity and inventiveness in wilderness, in time of crisis and keep motivated the workers: a spiritual leader.

IV. Biblical case three: Daniel and the spiritual intelligence in context of workplace

Daniel serves as example of a man of faith. He was in Babylon which was a great empire like Christians work today in empires (political empires such as superpower nations, economical and financial empires such as multinationals...). According to Theology of Work Project (2010), it is possible to work with spiritual principles and values, and the same time work effectively and Daniel is an example. Daniel was among the exiles brought to Babylon, and is called to work in a position of influence at the political level but in an environment hostile to God with occult practices. Should we leave this corrupt, pagan Babylonian government organization and seek only the organizations of the children of God? He chooses to work there while having a public life devoted to God.

But above all, Daniel and his three Jewish brothers were selected according to criteria decreed by the king of Babylon such as physical ability (beauty and flawless), language skills and others in order to follow one and Leadership training for being able to work in the royal court. The training was three years (Daniel 1).

A challenge both on the possibility of embracing moral corruption and idolatry by praising a man, the emperor. They enrolled in Babylonian education, but set limits to guard against 
assimilation into pagan culture. Daniel resisted the rich diet that was compulsory for all trainees, refusing to defile himself in (Daniel 1,8). How Daniel works with his supervisor is a vital part of the story.

Some Christians, when asked to do something against their conscience, they criticize or they adopt a conflicting position which seems to make them holier in their own view but Daniel found a third way, recognizing that his boss was sympathetic, but was in a difficult position.

Many secular workplaces (but certainly not all) offer a variety of opportunities such as personal gain, a good salary, job security, professional success and stature, comfortable working conditions and creative and interesting work. In themselves, these are good things.

But they tempt us with two serious evils:

- $\quad$ The danger of becoming so in love with good material things that we no longer wanting to risk these things by defending what God requires of us;

- $\quad$ The spiritual danger of believing that good things result of our own work or genius, or as a result of our service to another power than God. In addition, the workplace often requires accommodations which, in particular, themselves are not good, such as deception, prejudice, mistreatment of poor and helpless, yielding to unhealthy desires, taking advantage of others in their moments of need and many more.

Adopting a modest lifestyle, so that the attachment to money, prestige or power don't stop yourself from risking your job or career if you have to something contrary to the commandments, values or virtues of God. Despite the achievement of heyday of Babylonian education, position and wealth, Daniel and his friends were humble.

Is it possible to thrive at work while following God? People in all kinds of workplaces face this question every day, and many find the answer so difficult that they are tempted to abandon. Daniel, the central figure in the Book of Daniel, faces the question under extreme circumstances, provide and give examples that may be useful in today's workplaces.

The book of Daniel provides some principles for workplace :

-It is possible for Christians to practice their profession in non-Christian and even hostile environments.

-The life of prayer and communion with God must not be interrupted. Daniel prayed three times a day despite his responsibilities and leadership (Daniel 6,10).

-Knowing how to create connections or associate with others to support each other (Daniel $2,49)$. But also exchange executives share their professional concerns in relation to the Christian faith.

- Know how to maintain good relations with non-believers in the workplace, not to judge them but to witness to them faith in Christ while being a model.

-To be distinguished by competence and expertise as children of light who excel in everything.

-To maintain a firm faith in spite of persecutions of peers and chiefs. This kind of faith brings miracle and transformation in organizational leadership 
IV. Impact of spiritual intelligence: empirical studies Spiritual intelligence has many impact and some studies will prove it. A study conducted in France in a context where rationality is the cultural ideal. The spirituality of leaders must be placed in a context marked of things are to be in conformity with reason. The reason, by its Latin etymology ratio designates in the first place the notion of calculation, of computation, even of count. To be rational, according to standard economic theory, is to be able to solve an individual program and to conform to it, it is to be able to maximize its utility under constraint, if it is appropriate to choose in a context where several possibilities present themselves.

The France is heir to the philosophy of the Enlightenment, which sees the triumph of reason over the notion of faith or belief.

French leaders emphasize more the rationality in their work, having as a model that favored the deduction to induction, taking decision when it's coherent, logical, meaningful, and are poles apart from what is empirical, inductive, irrational or even passionate.

To understand the link and the impact of spirituality in the exercise of leadership of large French companies aged over 45 years, living and working in a context of rationality, a study carried out between 2009-2010. Among the variables considered there were gender (14 men and 6 women), the function performed (CEO, GD, DHR large groups , 3 of SME )...

The difficulties encountered along the course professional, the reactions and the means that were implemented for the overcome each of these difficult situations, and the place of spirituality.

Among the results, a first group of leaders who have low rationality and low spirituality, they wonder about the limits of rationality without going into other possibilities.

The second group of leaders has strong rationality and weak spirituality, spirituality being equated with religion and all its deviations.

The third group of leaders, have a weak rationality and strong spirituality, when it is necessary to decide they do not take as criterion the rationality but to the spirituality and its dignity taking into account also the sensitivity of the others to understand the others, to have the intuition and creates confidence in others and makes them dream.

The last group is made up of leaders with strong rationality and strong spirituality, they act in a kind of synchronization of two spheres, working in a holistic approach of sustainable development and as the questions of spirituality are not yet present in the day companies in France, some leaders feel a lack, a void.

For the interviewed leaders spiritual enlightenment delivers significant resources that help them to face hardships but those who not practice spirituality uses drugs in difficult moment for example.

This work makes it possible to identify a certain number of results, in particular how spirituality and rationality come into tension both on an individual and collective level, in terms of behavioral preferences, and of the sexes (man - woman). The development of the spirituality of the leaders questioned comes up against rationality. Rationality can constitute a limit to the development of spirituality. 
In France, for example, society sets up rationality as an ideal. Historically, rationality has been a recipe for getting out of the confusion of beliefs in the Middle Ages and made possible to offer more justice and security, reduction of suffering, lengthening of life, it could therefore become a model for evaluations of people.

The problem is that this paradigm underlies mistrust, intolerance towards anything that deviates from dogma despite the evolution of rationality towards taking into account its successive limits.

Spiritual enlightenment comes through the momentary repression of rationality.

The research allowed us to observe the spiritual progression of exemplary leaders and some of the effects in terms of professional effectiveness. The French leaders questioned live, because of the cultural importance attributed to rationality, an awareness which directs them in the first place towards rationality. French women leaders appear very sensitive and open to spirituality. The rise in power of spirituality implies avenues for extending the understanding of the phenomenon: in terms of its intensity, durability, manifestations, possible support, and organizational consequences.

Effective leadership is based on the synthesis of these three currents: sharing, management of emotions and the development of spirituality.

The results of this research show that the spiritual leader draws his resources in his education and the professional values to which he believes. More precisely, it draws its strength forgiveness, charity, self-care and others, creative dedication and welcoming others. Yet talking about spirituality in the company remains a challenge.

Women are more interested than men through the practice of spirituality what to trust in your intuition remains a pledge to access more easily to a spirituality the group of women who bring spirituality very much to the fore and do not hesitate to appeal to any external possibility of development. Many women leaders denounce the abuses of the ideal of rationality, which appears as the mark of a male stereotype. Male leaders are more comfortable talking about spirituality when they have experienced the development of grassroots religious faith. Unlike the women, the French male leaders interviewed are not ready to deal with spirituality in the workplace because spirituality (due to the religious connotation no doubt) appears to them as a private matter (Voynnet-Fourboul, 2011 ).

Fry $(2003,2005)$ conducted research in certain public and private organizations such as schools, the military units, large and small organizations public, private and social and its results show that there is a very positive influence the spiritual leadership of the quality of life at work, commitment, the productivity and growth.

For Linda Hindembrant (2011), among the impact of spiritual leadership in organizations there are performance in all the organization; job satisfaction which lead to great involvement; great performance of workers...

One of the most important benefits of spiritual intelligence is that it improves decisionmaking capabilities. A key requirement of a manager is to make decisions. The complexity of decision making seems to increase with one's seniority. Spiritual intelligence enables people to make decisions because they have a clear sense of purpose and principles by which they operate (Watson et al., 2018)

In the Bible, the impact of spiritual intelligence is demonstrated and Joseph, Bezalel, and Daniel served as case studies. The more leaders of organizations will use spiritual 
intelligence, the more leaders and followers will experience satisfaction, joy, accomplishment, and there will be transformation of our world.

\section{References}

Beardsley, L.M. (2004).Spiritual Intelligence and the Bible Presented at the $2^{\text {nd }}$ Symposium on the Bible and Adventist Scholarship, March 15 - 20, Loma Linda University, Dominican

Drigas, A, \& Mitsea, E. (2020) The Triangle of Spiritual Intelligence, Metacognition and Consciousness in International Journal of Recent Contributions from Engineering Science \& IT (iJES) · Marchhttps://doi.org/10.3991/ijes.v8i1.12503

Fry, L. (2003).Toward a theory of spiritual leadership ,The Leadership Quarterly 14 (2003), doi:10.1016/j.leaqua.2003.09.001

Fry, L. (2016). Spiritual Leadership in Global Encyclopedia of Public Administration, Public Policy, and Governance, January, DOI: 10.1007/978-3-319-31816-5_2353-1

Gardner, H. (2011). Frames of Mind: The Theory of Multiple Intelligences, Basic Books. Griffiths, R. (2020). Spiritual Intelligence, the neuroscience of spiritual intelligence.

Griffiths, R. (2021). "Spiritual Intelligence: A Higher Dimension of Intelligence for Enhanced Learning”, Global conference on Education and teaching, 25-27 June, Vienna.

Hildebrant, L.S. (2011). Spiritual intelligence : is it related to a leader's level of ethical development? Capella univiversity.

Jeffrey, P. (2017).Joseph: A Death and Resurrection Figure in the Old Testament and Second Temple Judaism. Durham theses, Durham University. Available at Durham E-Theses Online: http://etheses.dur.ac.uk/12425/

Master Sergeant Russell (2018). Immanuel Labor - God's Presence in our Profession: A Biblical, Theological, and Practical Approach to the Doctrine of Work", published by WestBow Press.

Nanus, B. (1995). Visionary Leadership. Wiley.

Theology of work Project (2010). Daniel and Work in Bible Commentary.

Voynnet, F.C. (2011). La spiritualité des dirigeants en situation de passage de leadership, Management Prospective Ed. « Management \& Avenir » 2011/8 n 4

Watson, M., Kuofie, M., Dool, R. (2018). Relationship between Spiritually Intelligent Leadership and Employee Engagement, Journal of Marketing and Management, 9 (2), 1-24, November, Argosy University, USA.

Winkler, A. (2011).Looking at the Future: Divination and Astrology in Ancient Egypt, thesis in Egyptology, Uppsala University.

Yiu-Wing, F. (1999). A Portrayal of Joseph in Genesis: the problematic nature of his claims to knowing God's intentions. PhD Thesis, University of Sheffield Yossi , S .(2017). Elisha Gray II, Joseph the Logistician: A Biblical Tale of Our Time in supply chain MIT, April 25.

Zohar, D., \& Marshall (2000). Spiritual intelligence. Bloomsbury Publishing 